\title{
CHARACTERISTICS AND ASSESSMENT \\ OF BIOLOGICALLY UNSTABLE FOREST PLANTATIONS OF VINNYTSIA USING INTERNATIONAL METHODOLOGY OF ICP-FORESTS
}

\section{Matusiak Mikhailo $^{1}$}

DOI: https://doi.org/10.30525/978-9934-571-89-3_101

Monitoring of forest plantations having damaged stability is a system for monitoring, estimating and forecasting changes in the forest ecosystems caused by the influence of negative factors. Negative factors affecting forests can be classified by the nature and origin, period and duration, nature of effect, scale and scope of influence, as well as by their rate and consequences [1, p. 15].

During the research, we examined pine, oak, hornbeam and beech forest associations. The sites for monitoring were located in these forest plantations. The sites intended for monitoring had about 100 wood species, for which indicators were determined according to the international methodology of ICP-Forests. For certain trees, the diameter, crown length in $\%$, Craft class (position of the tree in the forest stand according to its development), defoliation, dechromation, crown density in $\%$ on the trial siteswere determined (Table 1).

Table 1

Generalizeddata obtained on the monitored sites in the forest plantations of Vinnitsa region

\begin{tabular}{|c|c|c|c|c|c|c|}
\hline Species & $\begin{array}{c}\text { Diameter, } \\
\text { cm }\end{array}$ & $\begin{array}{c}\text { Length of } \\
\text { the crown, } \\
\%\end{array}$ & $\begin{array}{c}\text { Craft } \\
\text { class }\end{array}$ & $\begin{array}{c}\text { Defoliation, } \\
\%\end{array}$ & $\begin{array}{c}\text { Dechromation, } \\
\%\end{array}$ & $\begin{array}{c}\text { Crown } \\
\text { density, } \\
\%\end{array}$ \\
\hline $\begin{array}{c}\text { Common } \\
\text { pine }\end{array}$ & 24.0 & 27.3 & 2.2 & 23.1 & 8.0 & 62.7 \\
\hline $\begin{array}{c}\text { Common } \\
\text { oak }\end{array}$ & & 35.0 & 2.0 & 15.0 & 10.0 & 70.0 \\
\hline Beech & 17.9 & 48.3 & 2.6 & 13.6 & 2.5 & 73.2 \\
\hline $\begin{array}{c}\text { Common } \\
\text { spruce }\end{array}$ & 17.3 & 26.1 & 2.3 & 21.3 & 0.0 & 73.6 \\
\hline
\end{tabular}

Assessment of the state of forest plantations was carried out based on the established indicators of defoliation and dechromation of the monitoring methodology that are given in Table 2 .

According to the table, forest plantations with the rate of defoliation and dechromation of up to $10 \%$ are considered to be undamaged, $11-25 \%$ - conditionally damaged, 26-60 \% - moderately damaged, 61-99\% - heavily damaged. According to the given grouping, pine plantations should be classified as moderately damaged (rate

\footnotetext{
${ }^{1}$ Vinnytsia National Agrarian University, Ukraine
} 
of defoliation and dechromation exceeds $25 \%$ ), spruce, common oak, common beech, common hornbeam can be treated as conditionally damaged. The state of pine and spruce can be characterized as the worst. Since these forest plantations are adjacent to the city of Vinnytsia and motor transport is the main source of pollution, probable deterioration of their state is caused by the effect of aero-anthropogenic emissions. Coniferous breeds are less resistant to the effects of pollutants, so we analysed the content of heavy metals in the components of forest ecosystems. For the first time, the research on the content of heavy metals in the needles of common pine and common spruce was carried out [2, p. 27].

Table 2

\section{Characteristics of plantations according to the methodology of the international monitoring program}

\begin{tabular}{|c|c|c|}
\hline Damage rate & $\begin{array}{c}\text { Characteristics } \\
\text { of the forest status }\end{array}$ & $\begin{array}{c}\text { Rate of defoliation and } \\
\text { dechromation, } \%\end{array}$ \\
\hline 1 & undamaged & $0-10$ \\
\hline 2 & conditionally damaged & $11-25$ \\
\hline 3 & moderately damaged & $26-60$ \\
\hline 4 & heavily damaged & $61-99$ \\
\hline
\end{tabular}

In order to evaluate the content of heavy metals in the components of forest ecosystems, during the research we have selected the samples of needles of common pine and common spruce to estimate the content of heavy metals. Samples were selected in summer, analysis was carried out in the laboratory. Data on the content of heavy metals are given in Table 3 .

Table 3

The content of heavy metals in the needles of common spruce and common pine

\begin{tabular}{|c|c|c|c|c|c|c|}
\hline No & $\begin{array}{c}\text { Name of the } \\
\text { indicator }\end{array}$ & $\begin{array}{c}\text { Unit of } \\
\text { measurement }\end{array}$ & $\begin{array}{c}\text { Method of } \\
\text { testing }\end{array}$ & $\begin{array}{c}\text { Maximum } \\
\text { allowable } \\
\text { concentra- } \\
\text { tion }\end{array}$ & $\begin{array}{c}\text { Actual } \\
\text { value in } \\
\text { spruce }\end{array}$ & $\begin{array}{c}\text { Actual } \\
\text { value in } \\
\text { pine }\end{array}$ \\
\hline 1 & lead & $\mathrm{mg} / \mathrm{kg}$ & $\begin{array}{c}\text { State } \\
\text { standard } \\
30178-96\end{array}$ & 5.0 & 0.338 & 0.329 \\
\hline 2 & cadmium & $\mathrm{mg} / \mathrm{kg}$ & $\begin{array}{c}\text { State } \\
\text { standard } \\
30178-96\end{array}$ & 0.3 & 0.112 & 0.111 \\
\hline 3 & copper & $\mathrm{mg} / \mathrm{kg}$ & $\begin{array}{c}\text { State } \\
\text { standard } \\
30178-96\end{array}$ & 30.0 & 1.605 & 0.963 \\
\hline
\end{tabular}


According to the table, lead, cadmium and copper are accumulated in pine needles in the following concentrations: $0.338,0.112,1.605 \mathrm{mg} / \mathrm{kg}$. The content of these elements in spruce is as follows: lead -0.338 , cadmium - 0.112, copper $1.605 \mathrm{mg} / \mathrm{g}$. Evaluation of the content of heavy elements at maximum allowable concentrations (MAC) indicates the absence of significant accumulation of these elements in the tree needles. However, the indicated values of concentrations are given in general for plants. Thus, currently, MAC for the content of heavy metals in the needles of pine and common spruce, which could significantly affect the state of forest ecosystems, have not been determined. Therefore, even these concentrations may, to some extent, worsen the state of forest plantations.

According to the results of the estimation of forest plantations (Table 2), pine forests are characterized by the worst condition (defoliation and dechromationrates are $31.1 \%$ ), while spruce forests are slightly better (the rate is $21.3 \%$ ). However, the content of heavy metals in the pine needles is higher compared to that one in spruce. This indicates that, along with the impact of aero-anthropogenic emissions, other factors, including abiotic (primarily climatic) and bioticfactors, have a significant influence on the state of the forest ecosystems [3, p. 12].

\section{References:}

1. Metodichni rekomendatsii z monitoringu Ukrayni i rivnya [Methodological recommendations for Ukraine monitoring at level I]. Zatverdzheno Naukovo-tekhnichnoyu radoyu Derzhkomlisgospu Ukraini. Kharkiv: UkrNDILGA, 2002. 35 s. (Protokol № 1 vid 18 bereznya 2002 r.)

2. Diagnostika ta zonuvannya poshkodzhennya lisiv Ukraini aerotekhnogennim zabrudnennyam: metodichni rekomendatsiï [Diagnostics and zoning of forest damage in Ukraine by aeronautical contamination: methodical recommendations]. Zatverdzheno Naukovo-tekhnichnoyu radoyu Derzhkomlisgospu Ukrayni. Kharkiv: UkrNDILGA, 2008. 53 s. (Protokol № 4 vid 26 grudnya 2008 r.)

3. Romashov N. V. Rekomendatsii po organizatsii khazyaystva i sisteme meropriyatiy v rekreatsionnykh lesakh ravninnykh rayonov USSR [Recommendations on the organization of the organization and the system of measures in recreational forests of the lowland areas]. Kharkov: UkrNIILKhA, 1987. $15 \mathrm{~s}$. 